\title{
A Review of the Geology and Mineral Resources of Dahomey Basin, Southwestern Nigeria
}

\author{
Oli IC ${ }^{1 *}$, Okeke $\mathrm{OC}^{1}$, Abiahu $\mathrm{CMG}^{1}$, Anifowose FA ${ }^{2}$ and Fagorite VI ${ }^{1}$ \\ ${ }^{1}$ Department of Geology, Federal University of Technology Owerri, Africa \\ ${ }^{2}$ Department of Environmental Science, University of Louisiana, USA
}

Submission: August 05, 2019; Published: August 21, 2019

*Corresponding author: Oli IC, Department of Geology Federal University of Technology Owerri, Nigeria, Africa

\section{Abstract}

The Dahomey Basin is an amalgamation of inland/coastal/offshore basin that expanses from southeastern Ghana through Togo and the Republic of Benin to southwestern Nigeria. It is separated from the Niger Delta by a subsurface basement high referred to as the Okitipupa Ridge. The Cretaceous Abeokuta group is the oldest and the thickest group of sediment in the Dahomey basin. The Abeokuta group is composed of the Ise, Afowo and Araromi Formation. Ise Formation unconformably overlies the bedrock complex of Southwestern Nigeria. This unit consists of conglomerates, grits, coarse to medium grained sands interbedded with kaolinite. The conglomerates are imbricated and composed of ironstones at some localities. An age range of Neocomian-Albian is assigned to this Formation based on paleontological assemblages. The Afowo Formation comprises coarse to medium grained sandstone with variable but thick interbedded shale, siltstone and claystone. Using palynological assemblage, a Turonian age is assigned to the Lower part of this Formation, while the upper part ranges into Maastrichian. The youngest Cretaceous Formation in the group is Araromi Formation which is composed of fine-medium grained sandstone, shales, siltstone with interbedded limestone, marl and lignite. It is assigned a Maastrichian to Palaeocene age to this formation based on faunal content. The Abeokuta group is overlain by the Imo group (Ewekoro and Akinbo Formation, the Oshosun Formation, Coastal plain sands and recent alluvium. Dahomey basin is characterized with the abundance of mineral resources like kaolin, bentonite, phosphates, silca sand, limestones and gypsum.

Keywords: Dahomey basin; Mineral; Nigeria

\section{Introduction}

The geology of Nigeria as described by Obaje [1], comprises of three litho-petrological components, which are: Basement complex, the Younger Granites, and Sedimentary Basins. The Basement complex which consists of the Migmatite-Gneiss Complex, the Schist Belts and the Older Granites, is Pre Cambrian in age. The Younger granites which are predominantly magmatic rings that are Jurrassic in age are found mainly in Jos and parts of North-central Nigeria, while the Sedimentary Basins, which

are made up of the Dahomey Basin, the Sokoto Basin, the Chad Basin, the Benue Trough, the Mid-Niger (Bida/Nupe) Basin and the Niger Delta Basin comprisies of sediment fill of Cretaceous to Tertiary ages.

The Dahomey Basin is a combination of inland/coastal/ offshore basin that stretches from southeastern Ghana through Togo and the Republic of Benin to southwestern Nigeria [1] as shown in figure 1.

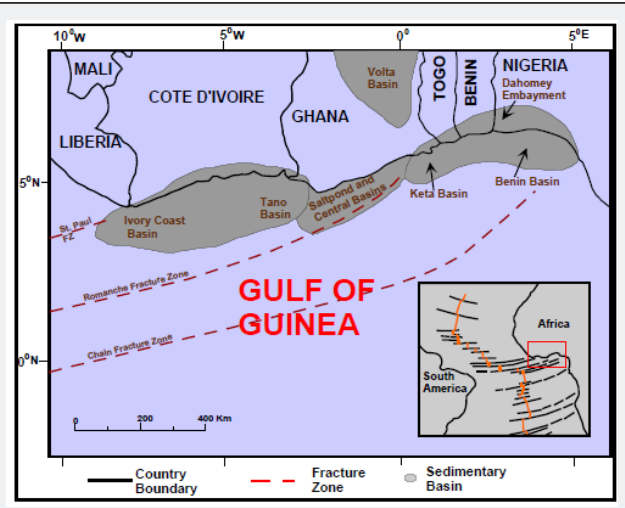

Figure 1: Regional map of the Gulf of Guinea showing the location of Benin (Dahomey) Basin in relation to other basins [2]. 
The Nigerian sector of the Benin (Dahomey) Basin is located in the southwestern Nigeria covering three different states, namely; Lagos, Ogun and Ondo [3] shown in figure 2. It is separated from the Niger delta by the Okitipupa ridge.). Nigeria as a nation is abundantly blessed with solid mineral resources, which are distributed equitably in all the States of the Federation.

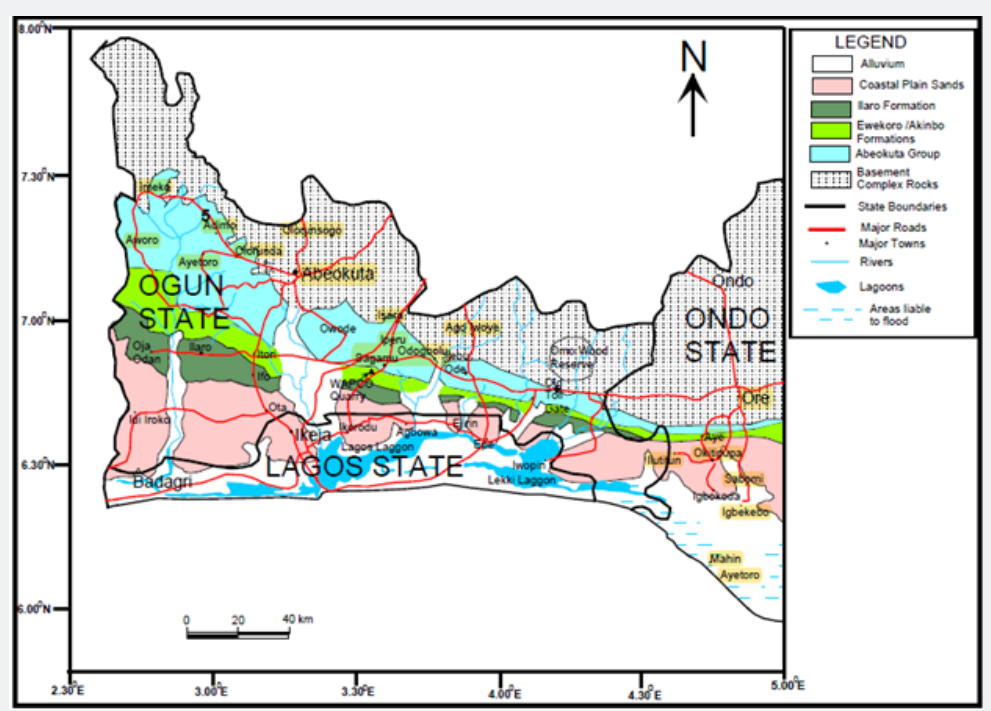

Figure 2: Geological map of Dahomey Basin in the Nigerian sector and the states located on the basin [3].

According to reports by the Geological Survey of Nigeria Agency, Nigeria has some 34 known major mineral deposits distributed in locations across the country and offers considerable attraction for investors [1]. Dahomey basin holds a huge prospect in respect to mineral exploration. The minerals which can be found in this basin are; sand, bitumen, limestone, feldspar, kaolin, granite, gemstones, Bentonite, gypsum and phosphate. The change of policy and new reform exercises

Table 1: Generalized stratigraphic column showing age, lithology, and sequence of the formations and tectonic stage of basin development in the Nigerian sector of the Benin Basin [3]. presently being embarked by the government of Nigeria has what it takes to bring about an improvement in the exploration and development of solid mineral resources in the Dahomey basin and the country in general.

The aim of this paper, therefore, is to attempts to update the knowledge on the structural setting, sequence stratigraphic successions and mineral resources of the Dahomey basin.

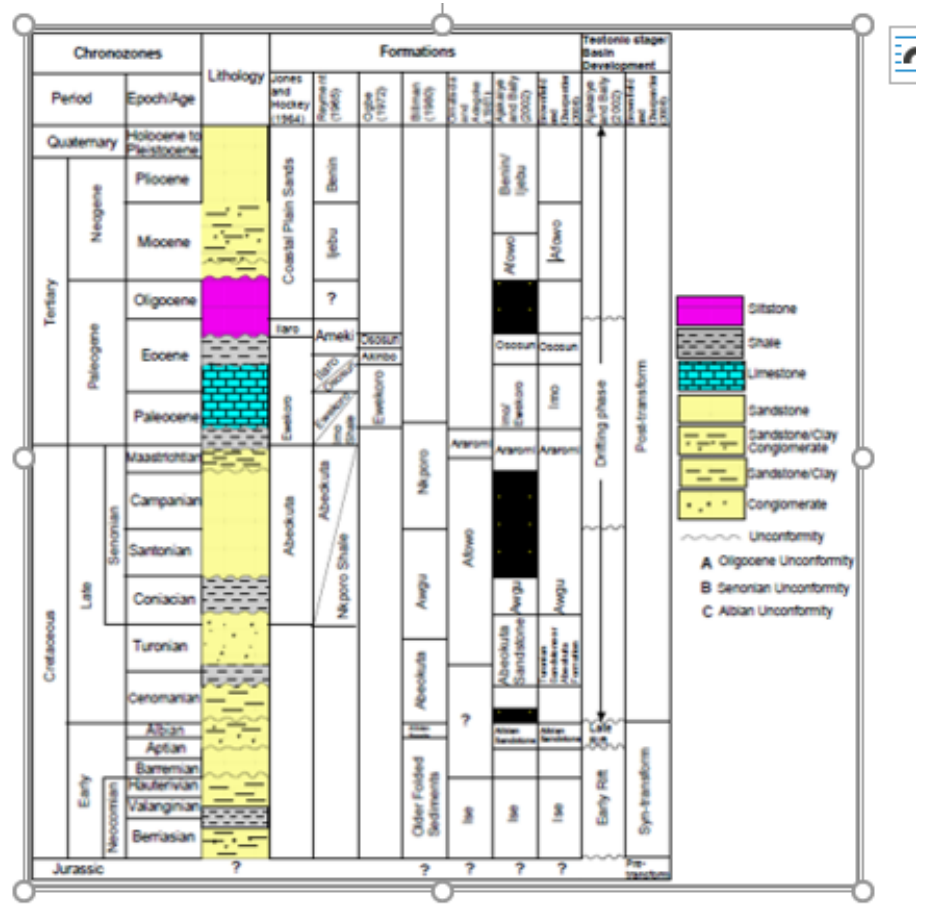




\section{Discussion}

\section{Stratigraphic setting}

Early study on the basin stratigraphy by Jones \& Hockey [4] recognized both Cretaceous and Tertiary sediments. Other subsequent workers recognized three chronostratigraphic units:

a) Pre-lower Cretaceous folded sequence,

b) Cretaceous sequence and

c) Tertiary sequence $[5,6]$ (Table 1$)$.

The Cretaceous stratigraphy as compiled from outcrop and borehole records consists Abeokuta Group sub-divided into three informal formational units namely Ise, Afowo and Araromi [5]. Olabode [7] described the formations as follows; Ise Formation unconformably overlies the basement complex and comprises coarse conglomeratic sediments. Afowo Formation is composed of transitional to marine sands and sandstone with variable but thick interbedded shales and siltstone. Araromi is the uppermost formation and is made up of shales and siltstone with interbeds of limestone and sands (Table 1). The Tertiary sediments consist of Ewekoro, Akinbo, Oshosun, Ilaro and Benin (Coastal Plain Sands) Formations (Table 1).

The Ewekoro Formation is made up of fossiliferous wellbedded limestone while Akinbo and Oshosun Formations are made up of flaggy grey and black shales. Glauconitic rock bands and phosphatic beds define the boundary between Ewekoro and Akinbo Formations. Ilaro and Benin Formations are predominantly coarse sandy estuarine, deltaic and continental beds.

A lot of controversy exists between the stratigraphy of the Cretaceous and Tertiary Formations in the Nigerian sector of the basin. This is due primarily to different stratigraphic names that have been proposed for the same Formation in different localities in the basin $[6,8]$. This situation can be fairly blamed on the lack of good borehole coverage and adequate outcrops for detailed stratigraphic studies.

Jones \& Hockey [4] established the name Abeokuta Formation for the mainly arenaceous strata with mudstone, silt, clay and shale interbeds that crop out onshore. Billman [9] subdivided the Abeokuta Formation into three lithostratigraphic units: The "Unnamed Older Folded Sediments", "Unnamed Albian Sands" and Abeokuta Formation. On the basis of age equivalence, he referred the remaining Cretaceous strata to the Awgu and Nkporo Shales. Omatsola \& Adegoke [5] disagreed with this nomenclature on two main grounds.

The first of these is that a rule of accepted stratigraphic practice is contravened because when the Abeokuta Formation was subdivided the same name was used for only one part of the succession. The second is that the application of the wellestablished Anambra Basin names: Nkporo and Awgu Shales to the Dahomey Basin solely on the basis of age is invalid. As a result, they proposed three new lithostratigraphic units, the Ise, Afowo and Araromi Formations, and referred these to the Abeokuta Group. In their classification, the Ise Formation is equivalent to the Unnamed Older Folded Sediments and the Unnamed Albian Sands, the Afowo Formation to the outcropping Abeokuta Formation, and the Araromi Formation to the Awgu and Nkporo Shales. The view that Anambra Basin lithostratigraphic names should not be used in the Dahomey Basin solely on the basis of age was supported by Okosun [10]. Furthermore, it is inappropriate to use the same names for lithostratigraphic units situated in different basins which are both widely separated from each other and have had different geologic history. This is also true if material for comparison of complex lithologic sequences is only present in deep well cores that are not readily available for study. Thus, the strata previously referred to as the Nkporo Shale were renamed Araromi Formation by Okosun [10]. The lithology of Ise and Afowo formations as defined by Omatsola \& Adegoke [5] show a high degree of similarity. Both are essentially sands and sandstones, but the latter contains thick interbeds of shale. This difference is not sufficient to warrant the establishment of separate lithostratigraphic units. The two formations were considered synonymous by Okosun [10]. In that study, it was observed that the Ise, Afowo and Abeokuta formations have similar lithologic and electric log characters.

The uppermost beds of Abeokuta Formation which crop out in the Ijebu-Ode area and in the shallow boreholes, at Itori, Wasimi and Ishaga onshore, consist mainly of fine- to coarsegrained sand and interbeds of shale, mudstone, limestone and silt [10]. These lithofacies correlate well with the upper portion of the neostratotype in the 0jo-1 Borehole. studied by Okosun [10]. Although the Afowo Formation contains shale interbeds, Okosun [10] emphasized that its essentially sandy character qualifies it along with the arenaceous Ise Formation, for inclusion in the Abeokuta Formation which also contains shale interbeds as demonstrated in the neostratotype described by him and as seen also in many surface outcrops. The use of the names Ise and Afowo. Formations was therefore discontinued and replaced by the Abeokuta Formation which has priority of publication and a wider accepted usage. The Abeokuta Formation was defined by Jones \& Hockey [4] to consist of grits, loose sand, sandstone, kaolinitic clay and shale. It was further characterized as usually having a basal conglomerate or a basal ferruginised sandstone [1].

\section{Mineral Resources}

Geological Survey of Nigeria Agency have actively engaged an active in the exploration for mineral deposits in Nigeria. The Dahomey basin like other Sedimentary Basins in Nigeria is found to be endowed with mineral resources. The mineral resources found in the basin, their locations and uses are listed below (Table 2);

According to data extracted from National Bureau of Statistics, as at 2016, Ogun State produced the highest tons 
of solid minerals among the 36 States and the FCT. The State produced 16,376,547.50 tons of solid minerals representing
$37.65 \%$ of the total tons of solid minerals produced in the year under review (Figure 3 \& Table 3).

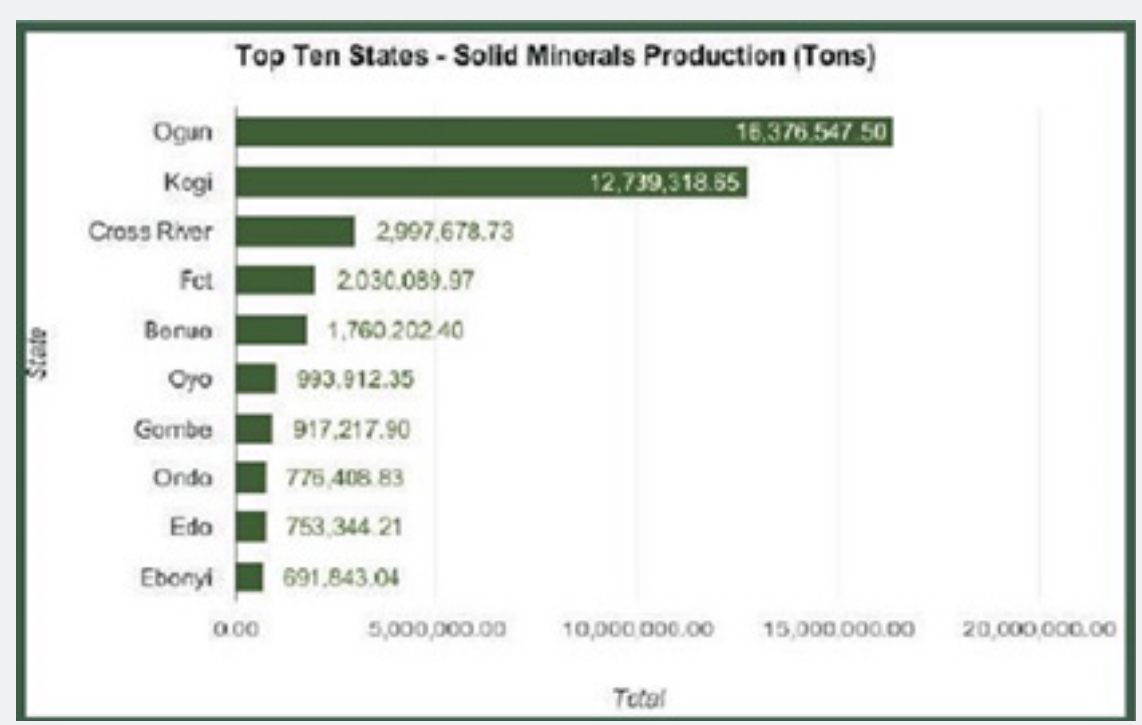

Figure 3: Solid minerals Production in Tons [11].

Table 2: Minerals occurring in the Dahomey basin, the states they are found in and their uses.

\begin{tabular}{|c|c|c|}
\hline Mineral & State & Use \\
\hline Kaolin & Ondo & $\begin{array}{l}\text { 1) Used in production of pesticides. } \\
\text { 2) Used in production of paint. } \\
\text { 3) Used in making rubber and plastics. }\end{array}$ \\
\hline Gypsum & Ogun & $\begin{array}{l}\text { Used in: } \\
\text { 1) Production of cement } \\
\text { 2) Plaster of Paris } \\
\text { 3) Manufacture of wallboard }\end{array}$ \\
\hline Limestone & Ogun, Ondo & $\begin{array}{l}\text { Used as: } \\
\text { 1) Soil conditioners for agriculture } \\
\text { 2) Building materials } \\
\text { 3) Reagent in desulphrisation of flue-gas. } \\
\text { 4) Raw material in making cements }\end{array}$ \\
\hline Bentonite & Ogun, Ondo & $\begin{array}{c}\text { Used in: } \\
\text { 1) Drilling fluids } \\
\text { 2) Decolorizing minerals } \\
\text { 3) Wine making } \\
\text { 4) Used as groundwater barriers }\end{array}$ \\
\hline Phosphate & Ogun & $\begin{array}{l}\text { Used in: } \\
\text { 1) Production of fertilizer }\end{array}$ \\
\hline Silica sand & Ondo, Lagos & $\begin{array}{l}\text { Used in: } \\
\text { 1) Water filtration } \\
\text { 2) Production of silicon chips } \\
\text { 3) Glass production }\end{array}$ \\
\hline Bitumen & Lagos, Ogun, Ondo & $\begin{array}{l}\text { Used in: } \\
\text { 1) Used for construction of roads. } \\
\text { 2) Water proofing to prevent water seepage. } \\
\text { 3) Lining canals to prevent erosion. }\end{array}$ \\
\hline Gemstones & Ogun, Ondo & $\begin{array}{l}\text { Used in: } \\
\text { 1) Fashion industry }\end{array}$ \\
\hline Granite & Ogun, Ondo & 1) Used in building and construction industry \\
\hline Feldspar & Ogun, Ondo & $\begin{array}{l}\text { 1) Used in production of floor tiles, table wares. } \\
\text { 2) Used in rubber and paint industry as a raw material }\end{array}$ \\
\hline
\end{tabular}




\section{International Journal of Environmental Sciences \& Natural Resources}

Table 3: Mineral type, State located and Production figure as at 2016 [11].

\begin{tabular}{|c|c|c|c|}
\hline S/No & Mineral Type & State & Production Figure (Tons) \\
\hline \multirow{3}{*}{1} & \multirow{3}{*}{ Sand } & Lagos & $548,246.23$ \\
\hline & & Ogun & 15,425 \\
\hline & & Ondo & 10,009 \\
\hline 2 & Limestone & Ogun & $1,333,860.73$ \\
\hline \multirow{2}{*}{3} & \multirow{2}{*}{ Feldspar } & Ogun & $119,666.67$ \\
\hline & & Ondo & $1,666.67$ \\
\hline 4 & Kaolin & Ogun & 22,000 \\
\hline \multirow{2}{*}{5} & \multirow{2}{*}{ Granite } & Ogun & $1,103,133.95$ \\
\hline & & Ondo & $105,791.66$ \\
\hline
\end{tabular}

\section{Conclusion}

Dahomey basin holds a lot prospect in the development of the Nigerian mining sector. These minerals when harnessed at full potential has what it takes to not only to increase the nation's GDP, but to also create employment on both skilled and unskilled labor platforms. For example, the bitumen found in the basin holds forth as one the second largest deposit in the world, but it still yet untapped.

\section{References}

1. Obaje NG (2009) Geology and Mineral Resources of Nigeria. SpringerVerlag Berlin Heidelberg, pp. 13-108.

2. Brownfield ME, Charpentier RR (2006) Geology and Total Petroleum Systems of the Gulf of Guinea Province of West Africa. U.S. Geological Survey Bulletin 2207-C.

3. Olabode SO, Mohammed MZ (2016) Depositional Facies and Sequence Stratigraphic Study in Parts of Benin (Dahomey) Basin SW Nigeria: Implications on the Re-Interpretation of Tertiary Sedimentary Successions. International Journal of Geosciences 7: 210-228.
4. Jones HA, Hockey RD (1964) The Geology of part of Southwestern Nigeria. Geological Survey of Nigeria Bulletin 31: 101.

5. Omatsola ME, Adegoke OS (1981) Tectonic evolution and Cretaceous stratigraphy of the Dahomey Basin. J Mining Geol 18: 130-137.

6. Billman HG (1992) Offshore stratigraphy and paleontology of Dahomey (Benin) Embayment. Nigerian Association of Petroleum Explorationists Bulletin 70(2): 121-130.

7. Olabode SO (2015) Subsidence Patterns in the Nigerian Sector of Benin (Dahomey) Basin: Evidence from Three Offshore wells. Ife Journal of Science 17(2): 456.

8. Coker SJL (2002) Field excursion guide to tar sand outcrops in Benin Basin. Nigerian Association of Petroleum Explorationists, MiniConference, pp. 32.

9. Billman HG (1976) Offshore Stratigraphy and Paleontology of the Dahomey Embayment. Proceedings, 7th African micropaleontology colloquium, lle-Ife.

10. Okosun EA (1990) A review of the Cretaceous stratigraphy of the Dahomey Embayment, West Africa. Cretaceous Res 11(1): 17-27.

11. Nigerian Bureau of Statistics (2016) The States Disaggregated Mining and Quarrying Data for 2016.

This work is licensed under Creative Commons Attribution 4.0 License DOI: 10.19080/IJESNR.2019.21.556055 